\title{
KEBIJAKAN PENDIDIKAN DI TINJAU DARI SEGI HUKUM KEBIJAKAN PUBLIK
}

\author{
Tri Puji Hastuti \\ Mahasiswa Program Pasca Sarjana Kebijakan Publik \\ Fakultas Hukum Universitas Sebelas Maret Surakarta \\ tripujihastuti220665@gmail.com \\ Soehartono \\ Dosen Fakultas Hukum Universitas Sebelas Maret \\ soehartonouns@yahoo.co.id
}

\begin{abstract}
$N$ ation education system is a system which integraded from all unit and education activities which related each other to reach national education purpose. Because of Indonesia education renewal demand, education wisdom has been through many changes. In this matter, education wisdom is viewed from public wisdom which is made by country, executive, legislative, judicative. Making decision about national education system is related with public wisdom. Public wisdom is new science because historically it appears in the midlle 1960 as a discipline in public administration and politic. The important matter which become attention is education wisdom that park from public wisdom. Research which is done by researcher is diagnostic research. This research uses doctrinal (normative) method and has purposeto know the base of public wisdom in education and analyze public wisdom in education
\end{abstract}

Keyword : Public wisdom, education wisdom, education

\begin{abstract}
Abstrak
$S$ istem Pendidikan Nasional adalah sebuah sistem yang terpadu dari semua satuan dan kegiatan pendidikan yang berkaitan satu denagn yang lainnya untuk mengusahakan tercapainya tujuan pendidikan nasional. Seiring tuntutan pembaharuan pendidikan di Indonesia, kebijakan pendidikan telah mengalami beberapa kali perubahan. Dalam hal ini kebijakan pendidikan dipandang melalui segikebijakan publik yang mana kebijakan adalah kebijakan yang dibuat oleh negara yaitu berkenaan denganlembaga eksekutif, legislatif dan yudikatif. Pengambilan keputusan tentang sistem pendidikan nasional berhubungan erat terhdap kebijakan publik, yang mana kebijakan publik merupakan ilmu yang relatif baru karena secara historis baru muncul pada pertengahan dasawarsa 1960-an sebagai sebuah disiplin yang menonjol dalam lingkup administrasi publik maupun ilmu politik. Persoalan terpenting yang menjadi sorotan adalah kebijakan pendidikan merupakan bagian dari kebijakan publik. Penulisan yang dilakukan oleh penulis ini merupakan penelitian dalam bentuk diagnostik. Metode penulisan yang digunakan adalah dengan menggunakan metode doktrinal (normatif), penulisan ini bertujuan untuk mengetahui landasan kebijakan publik dalam dunia pendidikan dan analisis kebijakan dalam bidang pendidikan.
\end{abstract}

Kata Kunci : Kebijakan Publik, Kebijakan Pendidikan, Dunia Pendidikan.

\section{Pendahuluan}

Kebijakan (Policy) secara "etimologi diturunkan dari bahasa yunani, yaitu polis yang artinya kota (city), kebijakan berkenaan dengan gagasan pengaturan organisasi dan merupakan pola formal yang sama-sama diterima pemerintah/lembaga sehingga dengan hal itu mereka berusaha mengejar tujuannya." Abidin menjelaskan kebijakan adalah "keputusan pemerintah 
yang bersifat umum dan berlaku untuk seluruh anggota masyarakat."

Kebijakan-kebijakan yang mengatur tentang pendidikan pun sudah sudah sangat banyak, sehingga memudahkan dan memberikan ruang gerak bagi insan pendidikan Indonesia untuk terus berinovasi dan membangun pendidikan yang berkarakter sesuai dengan harapan pendidikan nasional. Terdapat banyak faktor yang juga berperan dalam peningkatan kualitas pendidikan secara umum, beberapa faktor tersebut adalah faktor tujuan pendidikan, pendidik, peserta didik, alat pendidikan dan lingkungan. Jadi, pendidikan merupakan sebuah sistem yang tidak dapat dijalan kan jika salah satu sub sistem tersebut memiliki permasalahan dan mengakibatkan tidak optimalnya peran setiap sub sistem untuk mencapai tujuan yang telah dicanangkan.

Umumnya suasana dan proses pembelajaran, apapun kurikulumnya, masih mengutamakan proses mendengar, mencatat dan menghafal (rote learning), belum sampai kepada proses pembelajaran yang diharapkan UnitedNations Education, Scientific and Cultural Organization (UNESCO), yang terkenal dengan empat pilar belajar, yakni "learning to know, learning to do, learning to live together and learning to be.". Sistem Pendidikan Nasional adalah "sebuah sistem yang terpadu dari semua satuan dan kegiatan pendidikan yang berkaitan satu dengan lainnya untuk mengusahakan tercapainya tujuan pendidikan nasional."

Seiring tuntutan pembaharuan pendidikan di Indonesia, kebijakan pendidikan telah mengalami beberapa kali perubahan. Semenjak tahun 2003 telah diganti dengan UndangUnmdang Nomor 20 Tahun 2003, yang disyahkan pada tanggal 11 Juni 2003. Dalam pembukaan Undang-Undang Dasar 1945 alinea keempat menyebutkan bahwa "mencerdaskan kehidupan bangsa," dalam hal ini bangsa mencakup seluruh warga negara Indonesia baik warga yang belajar di sekolah-sekolah negeri, maupun yang belajar di sekolah swasta dalam hal ini kebijakan pendidikan merupakan bagian dari kebijakan publik.

Harold D Laswell mengatakan bahwa kebijakan publik adalah program pencapaian tujuan, nilai-nilai dan prktik-praktik yang terarah. Sedangkan Carl J Frederick mengemukakan bahawa kebijakan publik adalah serangkaian tindakan yang diusulkan seseorang, kelompok atau pemerintah dalam suatu lingkungan tertentu dengan menunjukkan hambatan-hambatan dan kesempatan-kesempatan terhadap pelaksanaan usulan kebijaksanaan tersebut dalam rangka mencapai tujuan tertentu. Atau ada pula David Easton yang mengatakan bahwa kebijakan publik adalah sebuah proses pengalokasian nilai-nilai secara paksa kepada seluruh masyarakat yang dilakukan oleh lembaga yang berwenang seperti pemerintah.

Dikaitkan dengan sistem pendidikan nasional, sebenarnya proses panjang perjalanan sebelum membuat kebijakan politik termasuk masalah pendidikan harus memperhatikan tahaptahap dalam proses pembuat kebijakan terkait denagn masalah pendidikan harus melihat realitas sosial, kultural dan sebagainya. No. 20 Tahun 2003 yang tertulis sebagai berikut :

\section{Pasal 4 ayat (1)}

Pendidikan diselenggarakan secara demokratis dan berkeadilan serta tidak diskriminatif dengan menjunjung tinggi hak asasi manusia, nilai keagamaan, nilai cultural dan kemajemukan bangsa.

\section{Pasal 4 ayat (3)}

Pendidikan diselenggarakan sebagai suatu proses pembudayaan dan pemberdayaan peserta didik sepanjang hayat.

Kedua Prinsip yang tertuang dalam pasal 4 ayat (1) dan ayat (3) di dalam Undang-Undang Sistem Pendidikan Nasional (sisdiknas) tersebut di satu pihak memperkuat terlaksananya dasar pendidikan nasional yaitu Pancasila, Undang-Undang Dasar 1945 dan di pihak lain akan dapat dilaksanakannya fungsi pendidikan nasional dan tercapainya tujuan pendidikan nasional sebagaimana tertuang dalam pasal 3 Undang-Undang sisdiknas, Yaitu mengembangkan 
kemampuan dan terbentuknya watak serta peradaban bangsa yang bermartabat serta berkembangnya potensi peserta didik menjadi manusia yang utuh.

Sebagaimana diketahui pada tahun 2016 ini Indonesia masuk dalam Masyarakat Ekonomi Asia (MEA), yang mana pendidikan harus mampu mengembangkan sumber daya manusia yang dapat menunjang pembangunan Indonesia sehingga bangsa ini dapat bersaing dengan bangsa-bangsa lain.

Sumber daya manusia yang bermutu sedikitnya memiliki tiga komponen yaitu, "kemampuan menguasai keahlian dan bidang ilmu teknologi, kemampuan bekerja secara profesional dan kemampuan menghasilkan karya yang bermutu."

Upaya "meningkatkan mutu pendidikan di Indonesia membutuhkan kebijakan yang tepat dari pemerintah, ini berarti pemunculan kebijakan itu harus dilandaskan pada orientasi tujuan yang kuat." Kebijakan yang dikeluarkan pemerintah Indonesia dalam bidang pendidikan tidak hanya berbentuk undang-undang saja.

Persoalan penting yang perlu disorot adalah apakah kebijakan pendidikan bagian kebijakan publik atau kebijakan pendidikan sebagai kebijakan publik.Permasalahan tersebut menjadi penting karena berkaitan dengan memosisikan pendidikan dalam konteks sektor-sektor publik yang harus dikelola secara serius dan besarnya tingkat urgensi bagi pemerintah didalam menetapkan prioritas program-program pembangunan.

\section{Metode Penelitian}

Penelitian ini adalah merupakan penelitian yang bersifat normatif (doktrinal), yaitu penelitian yang dilakukan dengan cara meneliti data sekunder (pustaka). Data sekunder terdiri dari bahan primer yang terdiri dari Undang-Undang Dasar 1945, undang-undang,peraturan perundang-undangan di bidang sistem pendidikan nasional. Bahan hukum sekunder yang terdiri dari literatur yang menunjang, baik jurnalmaupun hasil penelitian. Dalam penelitian normatif, data yang telah terkumpul, baik melalui inventarisasi bahan-bahan primer maupun penyelusuran bahan sekunder, dilakukan content analysis yang kemudian diolah menjadi premis-premis umum tentang norma-norma umum dalam sistem kebijakan pendidikan dari segi kebijakan publik. Selanjutnya dianalisis secara dedukatif yaitu suatu penalaran yang terpangkal pada peristiwa umum, yang kebenaranya telah diketahui atau diyakini dan berakhir pada suatu kesimpulan yang bersifat lebih khusus. Penarikan simpulan yang secara dedukatif mempergunakan pola berfikir silogisme yang tersusun dari dua buah pernyataan (premis mayor dan premis minor) dan sebuah kesimpulan.

\section{Hasil Penelitian dan Pembahasan}

\section{Landasan Kebijakan Publik Dalam Kebijakan Pendidikan}

Merupakan suatu kebutuhan bagi ilmuwan pendidikan, utamanya ilmuwan administrasi pendidikan untuk memahami studi mengenai kebijakan publik (publicpolicy) khususnya kebijakan pendidikan (educationalpolicy), Kepentingan ini erat kaitannya dengan peran yang diharapkan dari ilmuwan administrasi pendidikan, tidak saja nantinya diharapkan sebagai seorang perumus kebijakan pendidikan yang berkualitas apabila imuwan administrasi pendidikan terlibat dalam proses pembuatan kebijakan (policymaker) akan tetapi lebih dari sekedar itu, ilmuwan administrasi pendidikan diharapkan akan memberikan peran yang besar dalam memberikan koreksi terhadap berbagai kesalahan-kesalahan (ketidak tepatan) dalam perumusan berbagai kebijakan pendidikan yang telah dihasilkan oleh pemerintah selama ini. Dengan demikian studi kebijakan pendidikan akan memberikan dasar yang kuat bagi seseorang yang ingin mengembangkan profesi sebagai seorang analis kebijakan pendidikan. 
Pelaksanaan yang terdapat didalam sisdiknas memerlukan kebijakan untuk sebuah perubahan dalam peningkatan mutu, "diperlukannya kebijakan yang langsung bersentuhan dengan keperluan peningkatan mutu sekolah karena didalamnya berkenaan dengan proses pemberdayaan." Dalam hal kebijakan pendidikan inimengandung pengertian bahwa "sebuah kebijakan merupakan usaha untuk mendefinisikan dan menyusun basis rasional untuk melakukan atau tidak melakukan suatu tindakan."

Fuad Ihsan mendefinisikan pendidikan nasional adalah "sistem kelembagaan yang bertanggung jawab atas pengembangan dan pelestarian sistem kenegaraan Pancasila dan kebudayaan nasional."

Landasan kebijakan pendidikan terdapat pada pasal 31 Undang-Undang Dasar 1945 yaitu hak untuk mendapat pendidikan yang layak.Sebagai amanat dan mandat dari UndangUndang Dasar 1945 tersebut maka dikeluarkanlah Undang-Undang Nomor 20 Tahun 2003 Tentang Sistem Pendidikan Nasional (UU Sisdiknas), dalam rangka untuk menciptakan sistem pendidikan berdasarkan pada nilai-nilai kemanusiaan nasional dan keadilan dalam Pancasila, serta dalam rangka penegakan Hak Asasi Manusia (HAM) berdasarkan Pasal 28C ayat (1).

Kebijakan pendidikan merupakan tanggung jawab pemerintah dalam penyelenggaraan pendidikan nasional, negara seharusnya bertanggung jawab secar orisinil dan bertanggung jawab secara mutlak dalam mewujudkan cita-cita bangsa Indonesia untuk mencerdaskan rakyat Indonesia. Pendidikan nasional adalah pendidikan yang berdasarkan Pancasila dan UndangUndang Dasar 1945, yang berakar pada nilai agama, kebudayaan nasional Indonesia dan tanggung jawab terhadap tuntunan perubahan zaman.

Pendidikan merupakan barang dan jasa yang dimiliki oleh masyarakat umum (publik), yang mana didalamnya masyarakat mempunyai hak untuk mendapat pendidikan dan pengajaran, serta pendidikan merupakan kewajiban pemerintah Indonesia untuk melaksanakanya utamanya dalam memberikan kesempatan untuk belajar. Oleh karena itu pendidikan merupakan public goods, maka sudah seharusnya penelitian mengenai kebijakan pendidikan masuk pada ranah kebijakan publik.

UU Sisdiknas No. 20 Tahun 2003 menyatakan bahwa, Pendidikan Nasional berfungsi mengembangkan kemampuan dan membentuk watak serta peradaban bangsa yang bermartabat dalam rangka mencerdaskan kehidupan bangsa. Hadirnya UU Sisdiknas No 20 Th.2003 tentang konsep tanggung jawab pemerintah dalam pelaksanaan sisdiknas terdapat dalam Pasal 5 ayat (1) yang menyatakan ," setiap warga negara mempunyai hak yang sama untuk memperoleh pendidikan yang bermutu" selanjutnya dalam pasal 6 ayat (1) "setiap warga negara yang berusia tujuh sampai dengan lima belas tahun wajib mengikuti pendidikan dasar", Pasal 11 ayat(1) menyebutkan "pemerintah dan pemerintah daerah wajib memberikan layanan dan kemudahan serta menjamin terselenggaranya pendidikan yang bermutu bagi setiap warga negara tanpa diskriminasi:, pasal 11 (2) menyatakan, "pemerintah dan pemerintah daerah wajib menjamin tersedianya anggaran guna terselenggaranya pendidikan bagi setiap warga negara yang berusia tujuh sampai dengan lima belas tahun", Pasal 34 ayat (1) "pemerintah dan pemerintah daerah menjamin terselenggaranya wajib belajar minimal jenjang pendidikan tanpa biaya".

Pembahasan mengenai masalah kebijakan pendidikan nasional tentunya tidak akan terlepas dari pembahasan mengenai dimensi politik yang mengonstruknya. Dapat dikatakan bahwa segala kebijakan pendidikan pada dasarnya merupakan keputusan politik. Dapat diambil kesimpulan secara umum bahwa kebijakan pendidikan memang selalu bernuansa politis. Sistem pendidikan yang ditetapkan melalui kebijakan pendidikan tersebut sebenarnya adalah usahausaha pemerintah sebagai kelompok elit minoritas yang sedang berkuasa di sebuah negara untuk melanggengkan status kekuasaannya serta melestarikan hegemoni atas rakyat mayoritas yang menjadi sasaran implementasi kebijakan tersebut. 


\section{Analisis Kebijakan Publik Dalam Bidang Pendidikan}

Pendidikan merupakan hal yang sangat penting, dikarenakan biasanyatingkat kecerdasan manusia diukur dari seberapa tinggi orang tersebut mengenyam pendidikan. Melalui pendidikan setiap individu dapat memenuhi kebutuhan hidup yang ingin dia capai dengan cara bekerja. Kebijakan pendidikan secara kuantitatif dapat meningkatkan derajad rasionalitas dalam proses pembuatan keputusan di sektor publik.

Analisis kebijakan merupakan suatu prosedur berfikir yang sudah lama dikenal dan dilakukan dalam sejarah manusia. Menurut Duncan MacRae analisis kebijakan adalah "sebagai suatu disiplin ilmu sosial terapan yang menggunakan argumentasi rasional denagn menggunakan fakta-fakta untuk menjelaskan, menilai, dan membuahkan pemikiran dalam rangka upaya memecahkan masalah publik." Dalam hal ini analisis kebijakan merupakan suatu cara atau prosedur dalam menggunakan pemahaman manusia terhadap sesuatu hal dan untuk memecahkan suatu maslah kebijakan.

Analisis efisiensi pendidikan baik internal maupun eksternal, pendekatan analycentric menganggap bahwa pendidikan dapat dianalogikan sebagai industri, yang sama output pendidikanmerupakan fungsi dari berbagai faktor input pendidikan. Sumbangan masingmasing input terhadap output pendidikan dapat diukur secara tepat sehingga dimungkinkan untuk dilakukan simulasi yang mampu menghasilkan kesimpulan.

Secara kualitatif dari kebijakan pendidikan pada dasarnya merupakan proses pemahaman terhadap masalah kebijakan sehingga dapat melahirkan gagasan/pemikiran mengenai caracara pemecahannya. Masalah kebijakan pendidikan sendiri bersifat kualitatif sehingga proses pemahaman tersebut juga jenuh dengan pemikiran yang bersifat kualitatif. Pemahaman terhadap masalah kebijakan pendidikan dilahirkan dari cara berpikir dedukatif, cara berpikir yang dimulai dari wawasan teoritis yang dijabarkan menjadi satuan konsep yang lebih operasionaldan dapat dihubungkan dengan kenyataan. Wawasan teoritis sendiri tidak berdiri sendiri karena sangat tergantung pada subjektivitas seorang analis dalam memperspektifkan kebijakan pendidikan. Perbedaan wawasan tidak semata disebabkan oleh sifat dan jenis masalah kebijakan, namun cenderung diakibatkan oleh cara pandang berlainan atau perbedaan paradigma pemikiran dan filsafat pemikiran yang berlainan.

Kebijakan pendidikan berdasarkan UU Sisdiknas No. 20 Tahun 2003 diarahkan untuk mencapai hal-hal sebagai berikut:

a) Mengupayakan perluasan dan pemerataan kesempatan memperoleh pendidikan yang bermutu tinggi bagi seluruh rakyat Indonesia menuju terciptanya manusia Indonesia berkualitas tinggi dengan peningkatan anggaran pendidikan secara berarti.

b) Meningkatkan kemampuan akademik dan profesional serta meningkatkan jaminan kesejahteraan tenagn kependidikan sehingga tenaga pendidik mampu berfungsi secara optimal terutama dalam peningkatan pendidikan watak dan budi pekerti agar dapat mengembalikan wibawa lembaga dan tenaga kependidikan.

c) Melakukan pembaharuan sistem pendidikan termasuk pembaharuan kurikulum, berupa diversifikasi kurikulum untuk melayani keberagaman peserta didik, penyusunan kurikulum yang berlaku nasional dan lokal sesuai dengan kepentingan setempat, serta diversifikasi jenis pendidikan secara profesional.

d) Memberdayakan lembaga pendidikan baik sekolah maupun luar sekolah sebagai pusat pembudayaan nilai, sikap dan kemampuan, serta meningkatkan partisipasi keluarga dan masyarakat yang didukung oleh sarana dan prasarana memadai.

e) Melakukan pembaharuan dan pemantapan sistem pendidikan nasional berdasarkan prinsip desentralisasi, otonomi keilmuan dan manajemen.

f) Meningkatkan kualitas lembaga pendidikan yang diselenggarakan baik oleh masyarakat maupun pemerintah untuk memantapkan sistem pendidikan yang efektif dan efisien dalam menghadapi perkembangan ilmu pengetahuan, teknologi, dan seni. 
g) Mengembangkan kualitas sumber daya manusia sedini mungkin secara terarah, terpadu dan menyeluruh melalui berbagai upaya proaktif dan reaktif oleh seluruh komponen bangsa agar generasi muda dapat berkembang secara optimal disertai dengan hak dukungan dan lindungan sesuai dengan potensinya.

h) Meningkatkan penguasaan, pengembangan dan pemanfaatan ilmu pengetahuan dan teknologi, termasuk teknologi bangsa sendiri dalam dunia usaha, terutama usaha kecil, menengah, dan koperasiguna meningkatkan daya saing produk yang berbasis sumber daya lokal.

Berdasarkan uraian atau analisis tersebut dapat di pahami bahwa kebijakan pendidikan dapat disimpulkan sebagai suatu rangkaian kegiatan yang meliputi perumusan, analisis, implementasi, monitoring/pemantauan serta evaluasi seputar masalah pendidikan yang diterapkan dalam menjawab tantangan pendidikan dan diberlakukan secara periodik.

Ada beberapa prinsip mengenai kebijakan pendidikan sebagai kebijakan publik, prinsip tersebut, diantaranya:

a) Nilai-nilai pendidikan harus mewarnai setiap kebijakan negara dalam berbagai bidang sehingga aspek-aspek kemanusiaan, keadilan sosial, keadilan ekonomi, pemerintahan pembangunan, keadilan hukum mencerminkan keadilan suatu bangsa yang bermoral danbermartabat. Jadi, nilai-nilai pendidikan harus berperan secara proaktif untuk memasuki semua bidang yang berkembang dalam masyarakat sejalan dengan era globalisasi semakin cepat serta memberikan pengaruh yang besar.

b) Pendidikan harus terbebas dari intervensi kekuasaan dan konflik kepentingan. Namun pada kenyataannya pendidikan tidak dapat dipisahkan sebagai alat untuk merayu masyarakat secara umum untuk perebutan kekuasaan. Hal tersebut mengakibatkan penentuan pembuat kebajiikan pendidikan dalam hal ini pemerintah pusat akan dipengaruhi oleh nuansa politik dan sarat dengan kepentingan tertentu.

c) Nilai-nilai pendidikan harus menjiwai sistem perpolitikan dan prinsip penyelenggaraan negara dan tata kelola pemerintahan. Pendidikan berperan memberikan masukan berupa penguasaan kompetensi serta aspek keprofesionalitas dan tidak kalah pentingnya juga harus mengubah moral dalam dunia perpolitikan.

d) Nilai-nilai pendidikan harus menjadi spirit yang menjiwai kepribadian dan budaya bangsa yang menjunjung tinggi Bhineka Tunggal Ika. Pendidikan mempunyai peran penting yang bertugas untuk menyatukan dan memberikan keseimbangan bahwa masing-masing individu meskipun memliki sifat dan perilaku yang berbeda yang dilatar belakangi kebudayaan mereka, tidak menyurutkan untuksenantiasa saling menghormati dan menghargai.

e) Pendidikan harus menjadi garda terdepan dari suatu proses perubahan dan menjadi lokomotif perkembangan ilmupengetahuan dan teknologi. Karena pendidikan merupakan pusat atau inti dari perkembangan peradaban berbagai macam bangsa dengan cara mengubah pola pikir.

Nanang Fattah menyebutkan bahwa fungsi kebajikan dalam pendidikan adalah:

a) Menyediakan akuntabilitas norma budaya yang menurut pemerintahan perlu ada dalam pendidikan. Hal ini berkaitan dengan karakter kepribadian yang sangat beragam dan berbeda-beda.

b) Melembagakan mekanisme akuntabilitas untuk mengukur kinerja siswa dan guru. Perlu diupayakan pendirian suatu lembaga independen dan mandiri yang bertugas khusus untuk melakukan kegiatan evaluasi dan pengawasan. 
Berbeda dengan disampaikan oleh pongtuluran bahwa fungsi kebijakan sebagai berikut :

a) Pedoman untuk bertindak. Kebijakan pendidikan mempunyai posisi yang sentral dalam menentukan suatu acuan dalam implementasi program pendidikan serta sebagai tuntutan ke mana arah sistem pendidikan akan tertuju dan berjalan.

b) Pembatas perilaku. Hal ini dikarenakan kebijakan pendidikan tidak dapat dilepas dari norma serta aturan dalam setiap tindakan yang diaktualisasikan berkaitan dengan aktivitas pendidikan.

c) Bantuan bagi pengambilkeputusan. Kebijakan pendidikan sebagai ujung tombak dalam mengambil keputusan yang tepat dan benar setelah melalui serangkaian proses perumusan oleh para pembuat kebijakan pendidikan.

Kebijakan Pendidikan merupakan sebuah kebijakan publik, oleh sebab itu setiap programprogram dalam dunia pendidikan adalah program-program yang dirancang oleh pemerintah dalam rangka mengatasi permasalahan yang ada dalam pendidikan demi memenuhi kewajiban pemerintah dalam hal memberikan pendidikan bagi setiap warga negaranya, sebuah kebijakan dibuat untuk mencapai suatu pedoman dalam bertindak dan mengarahkan kegiatan dalam organisasi pendidikan. Pendidikan merupakan suatu kegiatan, proses, hasil dan ilmu yang pada dasarnya merupakan sebagai usaha dasar yang dilakukan manusia guna memenuhi kebutuhan hidup.

\section{Simpulan}

1. Undang-Undang dasar 1945 serta peraturan perundang-undangan telah menggariskan secara jelas politik hukumnasional terhadap kebijakan dan arah pendidikan di Indonesia. Pendidikan nasional telah memiliki landasan hukum yang kuat serta arah berupa visi dan misi yang merupakan pedoman bagi pemerintah dan masyrakat Indonesia untuk dilaksanakan. Undang-Undang Dasar 1945 menetapkan hak setiap warga negara untuk memperoleh pendidikan dan kewajiban pemerintah untuk "mengusahakan dan menyelenggarakan satu sistem pendidikan nasional. Undang-Undang Nomor 20 Tahun 2003 Tentang Sistem Pendidikan Nasional ini merupakan dasar hukum penyelenggaraan dan reformasi Sistem Pendidikan Nasional, yang memuat visi,misi, fungsi dan tujuan pendidikan Nasional, serta strategi pembangunan pendidikan nasional, untuk mewujudkan pendidikan yang bermutu serta relevan dengan kebutuhan masyarakat dan berdaya saing dalam kehidupan. Dalam UU Sisdiknas Pasal 5 ayat (1) menetapkan "hak setiap warga Negara untuk memperoleh pelayanan pendidikan yang bermutu". Dalam kaitan itu agar cita-cita yang tertera dalam Undang-Undang Dasar 1945 dan UU Sisdiknas dapat dijamin keterlaksanaannya, adanya standar nasional. Yang harus diikuti oleh para penyelenggara pendidikan di Indonesia perlu ditetapkan dengan menyadari kondisi indonesia sendiri.

2. Konsistensi regulasi pendidikan dalam perwujudan hak bagi setiap warga negara belum berjalan sesuai dengan ketentuan Undang-Undang Sisdiknas, sebab beberapa ketentuan pendidikan, diantaranya regulasi pendidikan jarak jauh, regulasi pendidikan dasar dan menengah, regulasi pendidikan tinggi dan regulasi badan hukum pendidikan masih belum konsisten dalam pembentukan peraturan pelaksanaannya. Realisasi kebijakan pendidikan sebagai tanggung pemerintah untuk mencerdaskan kehidupan bangsa belumlah berhasil, sebab upaya penyemerataan kesempatan pendidikan dan sasaran realisasi pendidikan nasional untuk menciptakan generasi yang berwatak cerdas dan kreatif masih berada dalam presentase terendah. 


\section{Daftar Pustaka}

\section{Buku-Buku}

Abidin dan Said Zainal. 2006. Kebijakan Publik. Suara Bebas. Jakarta.

Fuad Ihsan. 2005. Dasar-Dasar Kependidikan. Rieneka Cipta. Jakarta.

H. Haidar Putra Daulay. 2004. Pendidikan Islam dalam SISDIKNAS di Indonesia. Cet 1. Kencana. Jakarta.

Muchsin. 2007. Politik Hukum Dalam Pendidikan Nasional. Pasca Sarjana Universitas Sunan Giri, Surabaya.

Munawar Sholeh. 2005. Politik Pendidikan. IPE. Grafindo Khasanah Ilmu. Jakarta.

Soedijarto. 2008. Landasan Dan Arah Pendidikan Nasional Kita. Kompas. Jakarta.

Suryadi. Aceh dan H.A.R. Tilaar. 1994. Analisis Kebijakan Pendidikan, Sebuah Pengantar. Rosdakarya. Bandung.

Syarafuddin. 2008. Efektivitas Kebijakan Pendidikan: Konsep, Strateg Dan Aplikasi Kebijakan Menurut Organisasi Sekolah Efektif. Rineka Cipta. Jakarta.

Tri Wibowo Budi Santoso. 2006. Public Policy: Pengantar Teori Dan Praktik Analisis Kebijakan. Kencana. Jakarta.

Yoyon Bahtiar Irianto. 2012. Kebijakan Pembatruan Pendidikan Konsep, Teori, dan Model. RajaGrafindo Persada. Jakarta.

\section{Undang-Undang}

Undang-Undang dasar 1945

Undang-Undang Nomor 20 Tahun 2003 Tentang Sistem Pendidikan Nasional. 